\title{
THE TEACHER'S ACTIVITY PECULIARITIES IN THE FUTURE TEACHERS' SYSTEM PREPARATION FOR THE SPIRITUAL AND MORAL DEVELOPMENT OF ELEMENTARY SCHOOL PUPILS IN THE CROSS- CULTURAL SPACE
}

\author{
${ }^{1}$ Docent, Shevchenko Yuliia \\ Ukraine, Melitopol, \\ Bogdan Khmelnytskyi Melitopol State Pedagogical University; \\ ${ }^{1}$ Associate professor department of primary education
}

DOI: https://doi.org/10.31435/rsglobal_wos/31012019/6316

\section{ARTICLE INFO}

Received: 23 November 2018

Accepted: 27 January 2019

Published: 31 January 2019

\section{KEYWORDS}

future teachers of primary school, spiritual and moral development, cross cultural space.

\begin{abstract}
The article deals with the peculiarities of the teacher's professional activity in the system of training future teachers for the spiritual and moral development of primary pupils in the cross-cultural space. There are shows the role and influence the contest of education during process of professional training.
\end{abstract}

Citation: Shevchenko Yuliia. (2019) The Teacher's Activity Peculiarities in the Future Teachers' System Preparation for the Spiritual and Moral Development of Elementary School Pupils in the Cross-Cultural Space. International Academy Journal Web of Scholar. 1(31), Vol.2. doi: 10.31435/rsglobal_wos/31012019/6316

Copyright: (C) 2019 Shevchenko Yuliia. This is an open-access article distributed under the terms of the Creative Commons Attribution License (CC BY). The use, distribution or reproduction in other forums is permitted, provided the original author(s) or licensor are credited and that the original publication in this journal is cited, in accordance with accepted academic practice. No use, distribution or reproduction is permitted which does not comply with these terms.

Introduction. At the present stage of development in the conditions of the education system reformation Ukrainian society get a task - forming a competent, creative, socially active person. The main instrument in this process is modern education, especially its initial link. After all, it is precisely in the elementary school that the foundation is laid, which ensures further comprehensive and harmonious development of the child in the future. In view of this, the problem of students' preparation peculiarities for teachers of professional higher educational institutions to the improvement of the of primary school age children spiritual and moral sphere is urgent.

The problem of preparing future teachers of elementary school for the formation of spiritual and moral values younger schoolchildren during the study at the initial time has not been comprehensively studied, that is, there is no holistic study devoted to the coverage of the substantive and procedural principles of the training students of specialized universities to the organization of moral and spiritual development of children 6-10 years. In the context of our research work, the activities of pedagogical universities teachers in the organization of the educational process, one of the educational results of which is the knowledge of students about the peculiarities of the spiritual and moral sphere of children of primary school age, is one of main importance.

Research results. In order to determine the peculiarities pedagogical universities teacher role in preparing students for the formation of spiritual and moral values system of children in the crosscultural space, in our view, it is necessary to first determine the peculiarities of the professional teacher training of the elementary school teacher in these conditions.

Let's dwell further.

The analysis of pedagogical sources shows that they do not contain the generally accepted interpretation and definition of the concept of professional readiness of the future teacher. At the current 
stage of development, Ukraine education is undergoing significant changes and is undergoing reforms whose characteristics are unified for all participants in the educational process (teachers, pupils, parents) both teachers and students are not prepared to teach and study in new, non-traditional conditions. As stated in the Concept of general education, «changes in the content and structure of general secondary education are of a profound nature and require solving the problems of preparing a teacher who is aware of his social responsibility, constantly cares about his personal and professional growth, is able to achieve new pedagogical goals. From this perspective, the role of the teacher lies not only in ensuring the transmission of knowledge, but also in being a man of culture and of universal values. In the research works of V. Molodinchenko, T. Oleksenko and others is noted that values of human can be classified as follows: scientific («values are prudent, acquire the status of theoretical constructors»); spiritual-moral («value as a socio-cultural phenomenon now includes not only an emotional component, but also a conscious belief in a higher being, identical with the very ethical existence of man, inseparable from the meaning of human being»); material («that which can satisfy the living needs and interests of a person»); socio-political («positive orientations of people to various objects and states of socio-political existence, the notion of the most important and significant in the socio-political sphere»). According to the author, these values should be formed at the child during the study, and therefore it is precisely to the development of these values and must be ready for the future teacher [3].

Thus, the purpose of the professional activity of a teacher of a pedagogical university is not the transfer of concrete, subject knowledge, skills, but the provision of students with systemic knowledge, which is a general precondition for the formation of a competent specialist. Therefore, the issue of improving the system of pedagogical education in Ukraine according to new priorities in the field of training future teachers is the subject of research by scholars (L. Kondrashov, V. Lugovy, A. Pihota, D. Karyuchenko; W. C. Bower, J. J. Voight etc.). Identify the following scientific approaches to the implementation of the training of the future teacher: systemic, professional, activity, personally oriented, acmeological, axiological, culturological, competency, technological aproaches. In our opinion, the application of the above-mentioned systems in professional training will provide an effective result for the readiness of future teachers to form the of spiritual and moral values system of elementary school age children.

In the systemic approach, the problem of professional training is considered as a pedagogical phenomenon, which interconnects elements that are united by common functions and purpose, the unity of management and functioning. In this approach, the integrity structure of the teacher personality is considered in the unity of the communicative, vocational, pedagogical and cognitive components of the orientation. A professional cross-cultural training of the teacher is considered as a set of needs and motives, the intellectual sphere and its emotional characteristics.

A professional approach to the training of a future teacher is defined by a system of interrelated elements and actions characterizing the teacher's personality. In particular, his professional orientation, knowledge of the fundamentals of science, psychology, possession of pedagogical skills and the attraction to continuous self-education [3]. A professional training is the result of realization of a certain complex of ideal requirements for professional activity. Thus, the personality maturity of the teacher is an integral part of the development of his professionalism: the personality traits of the teacher significantly affect the professional activity, and professional activity is an important factor in the formation of the individual [1, p. 33].

Activity approach to the identified problem, is guided by a holistic view of pedagogical activity, its functions, educational tasks, relationships and ways of communication and is the main form in the form and contents of the structure of the professional training of the future teacher $[4,11]$. The most important characteristics of the activity approach are tasks that have to be solved by a specialist in professional activity; skills and abilities, personality traits; spiritual-moral and value orientations and settings. Activity approach involves mastering future teachers of elementary school through a system of professional pedagogical competencies [1, p. 57].

Personality-oriented approach gives the teacher a priority in the effectiveness of pedagogical activity as an independent value of pedagogical interaction. In particular, the value of the teacher's personality is considered as a collection of his individual and personality traits and qualities, through which the scientific laws and regularities of pedagogical science are fully researched in the practice of education and training [1, p. 30]. Under such conditions, the future teacher forms a readiness for work based on knowledge of modern pedagogical technologies, an understanding of their individual essence and a personal pedagogical concept and personnel-technology. In particular, the comprehensive development of the individual's identity of each student, while at the same time supporting individual characteristics and ensuring the formation of those who learn, the ability to live in society, the skills of 
effective cooperation with others and appropriate professional skills; cultivating in the personality of the another person's value; assertion by the future teacher of a positive personal essence of his pupils (I. Bekh); implementation of personally oriented content and teaching technologies, maximum individualization and subject orientation of the educational process, creation of conditions for selfeducation and self-development, meaningful determination by students of their capabilities and vital values (O. Pekhot). In our opinion, today concrete methods of realization of personally oriented pedagogical education have already emerged: expression of respect for the student's personality and recognition of its uniqueness; the need to ensure the dialogic nature of the educational process; realization of ideas of co-creation and cooperation both in the educational process and in scientific and experimental work; the use of methods and techniques of partial individualization of training [3, p. 34]. In this approach, the preparation of a future teacher of elementary school is oriented towards the acquisition of atypical skills for traditional education: to disclose their personal vision to the students; to intensify their processes of experience; «feel» the inner world of another, his personal needs; to carry out dialogue; improvise; to be a playwright, director and participant of some or other pedagogical situations (O. Rudnytska). Here, some scholars include the subject approach, which is significant for analyzing the problem of professional training of the primary school's future teacher. After all, in the process of the future students becomes the subject of socio-cultural relations - labor, communication, knowledge and mastered these activities, achieving a professional result $[4,26]$; thus forming personal experience of the creative nature and developing the ability to comprehend their individual reactions, without which it is impossible to comprehend the depth of artistic content $[1,30$ 31]. In particular, in the psychological and pedagogical studies of the theoretical methodological level, the idea of training a future teacher as a «subject of cognitive activity in higher educational establishments, an educational-professional in the course of pedagogical practices that can purposefully regulate their professional development» is traced [7, p. 7]. However, today there is still no psycho-pedagogical substantiation of the mechanism, conditions and ways of student transition from the position of the professional training subject to the position to subject of individual professional development throughout life [7].

The acmeological approach involves the activity of the instructor of a professional higher educational institution as one that aims at the development of personality at the stage of maturity and the achievement of its peaks in social and natural development. Namely, personal and professional maturity as the highest degree of person's socialization and professionalization. In particular, the formation of the mature person ability to act in changing and uncertain conditions, to maximize the use of the personality of their resources for optimal correlation with society, strengthening the role of self-development in an adult [1,14-15]. Under such conditions it is the formation of a future teacher disciplines of a steady striving for success, self-realization of creative potential, life strategy of development of a specialist's creative personality, self-improvement of professional activity.

Axiological approach to the study of the problem of the professional training of a future specialist in relation to the analysis of the content of pedagogical ideas, theories and concepts in view of their relevance or inconsistency with the needs of the individual and society. In the structure of the professional image of the future teacher, spiritual and moral-value orientations influence the formation of an anthropocentric view of the student's personality, humanistic orientation; on his interests, inclinations and abilities [4, 26]; values play the role of pedagogical activity's regulator, form the structure of the teacher's personality, act as a certain social standard, a criterion for measuring pedagogical actions [4]. In this approach, the process of vocational training should contribute to the formation of future teachers of elementary school value attitude towards the personality of the future pupil, the educational and socio-cultural environment.

Culturological approach in the epicenter puts the person as a free personality, which is capable of personal determination in culture $[7,71]$ and is based on the uniqueness of each subject of educational activity, on ensuring the conditions for its development in the context of an individualized approach in a personally developing educational system that provides socio-cultural self-development of the individual. The purpose of professional training is a person of culture, content-culture, as an environment, and cultural development as a way of human development in culture. Under such conditions, the preparation of the future teacher is based on the formation of the subject's individual qualities, the disclosure in the educational process of the integral and harmonious picture of the world, full of sensory sensations, with full reflection in it of cultural phenomena, in particular artistic [7, 27].

Competency approach reflects the integral manifestation of professionalism, which combines the elements of professional and general culture (the level of education sufficient for self-education and independent decision of cognitive problems), the experience of pedagogical activity and pedagogical 
creativity, which is specified in a certain system of knowledge, skills, readiness for professional activity [4, 28]. In this approach, the training of a future teacher is aimed at understanding students' personal trains of activity, needs and interests; aspirations and value orientations; motives of activity; representations about their social roles; self-esteem of personality traits and qualities, professional knowledge, abilities and skills, professionally important qualities; regulation of their professional formation. And it manifests itself in modern creative forms of the implementation of types of professional activity, deep scientific and theoretical knowledge about the subject of activity and requires the expression of physical, mental, intellectual, spiritual qualities and characteristics of the person $[4,157]$.

In the technological approach to the professional training of the future teacher systemidentifier element is the technology through which the interaction of the teacher and students [5, 82], organization of work of the teacher, increase of pedagogical skill. In particular, the reflexive component of this approach is negligible, borrowing methodological ideas about system and information technologies. Regarding professional training, its possibilities are limited only by the process of student training. In this approach, the training of a future specialist in artistic disciplines requires the design of specific pedagogical situations that would actualize the need for self-expression in the educational process. This is what helps a person to fully reveal his potential, talents, abilities. That, in turn, contributes to the formation of a pedagogical mastership higher degree for future teachers - pedagogical innovation.

In modern conditions, new requirements arise for the future elementary school teacher preparation, who put forward the task of forming his own self-determination, the value-moral principles of his own personality, an incentive to implement democratic and humanistic principles in future pedagogical activities, and to increase the level of his general pedagogical and professional culture. It is only possible to achieve this with the correct organization of the educational process of applicants for higher education. The essence of this is to understand and study pedagogical experience, to analyze the causes of difficulties, to design ways to overcome them, to predict the outcomes and consequences in the pedagogical process, to choose the best pedagogical technologies. All of the above is an important factor for the organization of the work of teachers of specialized universities. The development and introduction into the educational process of the higher school of pedagogical technologies contributes to the enrichment of vocational and pedagogical, in particular vocational and methodological training, by filling them with new content, forms, methods and methods of learning, creating new means of formation. This is because the technological literacy of the future teacher allows him to realize his true vocation, to more realistically evaluate potential opportunities, to look at the pedagogical process from the standpoint of the final result. I would like to add that familiarizing students with a wide range of teaching and practice of pedagogical technologies and acquiring skills and experience to carry out pedagogical activities in various conceptual systems creates the natural conditions in which the student from the object of professional training becomes a subject of individual professional development. The mentioned approaches to the professional training of higher education graduates are realized in the following principles: humanization, democratization, continuity, personification, systemicity, dialogue, consistency of the environment, multiculturaly, cultural correspondence, cross-culturaly. The content of professional training of future teachers is conditioned by such modern trends in the development of education and civilization as: globalization, regionalization, individualization, professionalization, integration. It should be noted that the training of future teachers for professional activities is related to the prospects of society in general and is in direct relation with the existing socio-cultural conditions of society, covering certain qualification and competence characteristics of a specialist.

In the context of our research, the issue of the influence of the cross cultural educational environment on the activity of pedagogical universities' teachers during the preparation of higher education students for the formation of the system spiritual and moral values in children of elementary school age is also important. In our opinion, the multiculturaly of Ukrainian society and the state policy proves the relevance of the subject of our study, since the key concept of any culture is values that include both spiritual and moral ones.

The system of cross-cultural value orientations is one of the most important components of the structure of the person, occupying the boundary position between it a motivational-needful sphere and a system of personal meanings.

The concept of «cross-cultural values» should be considered everywhere the interpretation of the notion of value, value orientations that are basic in this problem. In the scientific and pedagogical literature values are the properties of material objects and phenomena of social consciousness, which characterize them meaning for society, class and person. In the Ukrainian pedagogical dictionary 
valuable orientations are considered selective, relatively stable system of orientation interests of the personality, oriented to a certain aspect of social values [6,357].

Also «cross-cultural values» as a special complex socio-cultural and socio-psychological education, the result of a complex process of self-determination a person in the social space in relation to himself, another person and the attitude of the person relative their own and another culture $[2,4]$.

Under the cross-cultural values, we mean the set of values that involves national identity, interethnic tolerance, intercultural communication and interaction, cross-cultural adaptation as structural components of the modern personality.

In the process of intercultural contacts, there is a huge difference between how the same values are perceived by people of different cultures. Among a huge number of diverse perceive, nevertheless, it is possible to allocate a group of those that coincide both by the nature of the assessments, and for content. Such values have been called universal, or universal. The the universal character is conditioned by the fact that the basic features of such values are based on the biological nature of human and the general properties of social interaction. For example,

There is no culture in the world where it would have been positively valued to kill, lie and theft. In each culture, there are only their boundaries of tolerance of these phenomena, but their overall negative evaluation unambiguous.

Modern pedagogical studies reveal the diversity of cross-cultural upbringing. In particular, the works of I. Bekh are aimed at the subject-subject activity and the hierarchy of values, E. Zaredinova - the historical and cross-cultural context in family education, G. Nazarenko scientific research is related to the cultivation of a culture of interethnic relations, the study of B . Orzhehovskaya - on preventive education and the prevention of deviant behavior in the relationships of children, the work of K. Chorna aimed at the cultivation of civil and humanistic values in pupils of a secondary school. On the basis of the analysis of scientific sources, the concept of «cross-cultural values» is defined by us in a broad sense as a set of ideals, values, beliefs, relations between people, norms of behavior and etiquette that are formed at the intersection of two or more cultures (ethnic groups, peoples) as a result of their interaction and mutual enrichment, and in the narrow - as the common values that arise in the interaction, the mutual influence and interpenetration of two and more cultures. Such values are a conscious choice of personality and a condition for the functioning of a democratic society, reflecting a positive attitude towards other cultures, people, life in general and regulating norms and rules of conduct in society. The sensitivity of the studied cross-cultural values to children of elementary school is provided by their ageold peculiarities and allows to distinguish the following basic values: tolerance, openness, contact, selfesteem, justice. Tolerance for the primary school age is considered as tolerance in the pupil's team and to another person, mutual respect, courtesy. Openness as a cross-cultural value for primary school age pupils is a positive interest, interest and passion for one's or another culture. Contact as a value is the readiness for the joint activity of children in a new social environment for them - the school where the educational activity is leading. In the life of a junior schoolboy, self-esteem is based on a positive selfesteem, respect for oneself, national cultural knowledge and ideas about the achievements of one's and another's people, a sense of pride in their own and another culture that promotes awareness of belonging to a particular nation or ethnic group. Justice implies the democratization of relations, the ability to initiate equal and equal treatment for people in general, and for representatives of their own and another culture (distribution of social roles, responsibilities in class, etc.). All these cross-cultural values contribute to the development of good-neighborly relationships among children on the basis of friendship, peaceful coexistence, responsible attitude and respect for their native land, the formation of skills for dialogue and the development of critical thinking.

According to the results of the analysis of psychological and pedagogical works, we have defined the structure of cross-cultural values as a set of cognitive, emotional-value, activity-behavioral and self-regulatory components, which are organically interconnected and determine the main directions of education of elementary school age pupils. This structure is taken into account when developing criteria that are identical to those components. Thus, indicators of a cognitive criterion are knowledge of rules and norms of behavior in a team (in school, family, guests, in transport, on the street); the language of your own and other culture (words of greetings, farewells, requests, wishes, etc.); traditional style and organization of everyday life; holidays, traditions and achievements of one's and another's culture; emotional and value - humanistic attitude to any culture; understanding of the equivalence of cultures; openness, interest, positive orientation to interaction; activity-behavioral - the ability to listen, to apologize, to give in, to realize their mistakes, to adhere to the etiquette of their own and other culture; self-regulatory criterion - adequacy of self-esteem, expansion of the sphere of knowledge, skills and abilities in cross-cultural relations. 
Given the content and peculiarities of the formation of spiritual and moral qualities in children of primary school age, we can assert that the future teacher of the profile institution needs to solve a number of tasks:

- to help future educators to acquire the skills of organizing and conducting educational events on the basis of cultural material based on the experience of two cultures to reveal the creative potential of students;

- to form the ability for future educators to organize independent search activity (library search and presentation in three languages at reading lessons of proverbs and friendship letters, hospitality, etc.);

- to develop the skills of future teachers to team up the children's team, to disclose shy students, to teach children to cooperate in a group, to present the results of their work;

- to develop the ability to see the interconnection of Ukrainian and any other culture through awareness of the common and specific or specific;

- to expand both personal and professional outlook, knowing one another and other cultures

- to help awareness of the self-worth and value of another person.

In our opinion, the implementation of a system of formation of cross-cultural values for future specialists should be carried out in stages. Students get knowledge of cross-cultural values, the features of cross-cultural contacts at the cognitive stage in the process of studying individual professionally directed disciplines. Students are interested in the values of their own and other cultures, which affects the motivational-emotional sphere. Youth acts as bearers of the customarytraditional ritual, in which it is brought up, and becomes a participant in constant cultural interaction. Students need to know how their customs, traditions, ceremonies, and other ethnos with whom they communicate. The stage of transformation of cross-cultural values into personal achievements involves the formation of a complex of skills and competences for future teachers of the elementary school that enable them to better understand and understand the content of cross-cultural values, shape the need for mastering them, the desire to use knowledge about their own and other cultures in their own life activities. The stage of designing cross-cultural values occurs when students pass different types of pedagogical practice in school. Continued education of multiculturalism, respect for crosscultural values takes place in the next line of education - elementary school, where refinement, expansion, deepening of knowledge both at the lessons, and in extra-ordinary time is carried out. Therefore, a modern teacher should take this into account when organizing the educational process with junior pupils. So, at the lessons of literary reading children should be introduced to the works of foreign authors, different folk genres. At lessons of labor training, students can make boxes made of vines, trees, straw, corn swags, which is typical, for example, for Hungarian culture. Art lessons from other peoples (Slovak, Hungarian, Czech) are used on holiday holidays, primary school pupils perform folk songs of neighboring countries in the original language, and put out fragments of theatrical performances of foreign cultures. In addition, it is advisable to organize national holidays, when children come to school in their own national costumes, and parents treat national cuisine.

The multicultural education of students will contribute to the formation of their cultural identity and the understanding of their cultural differences between people. The correctness of the solution of these problems involves a high degree of tolerance, readiness for intercultural dialogue and cooperation. During the hours of communication, it should be stressed to future specialists that the causes of the emergence of intercultural conflicts at all levels (interpersonal, intergroup and international) are: the diversification of individual and collective interests as in one culture, and in others (at the same time, individually-favorable behavior strategies lead to collective loss); the presence of competition between the parties, and the distortion or limitation of information resources between cultures. Further discussions with future classroom teachers of the problems of intercultural conflicts make it possible to realize that conflicts can cause, deepen, expand and support factors such as: lack of understanding of the values of other cultures; information and misinformation, inaccurate information, outdated data, criticism, subjective information about a particular culture or its lack; cultural information is still unknown that is perceived as unlikely due to the views, experience or dubious reputation of the source itself; contradictory information about a particular culture; unpleasant information of concern; complex information is not fully integrated and understood; too much information for timely analysis, understanding and evaluation.

The main tasks of the cross-cultural education of the future teacher of elementary school can be described as mastering students knowledge about the cultural diversity of the world; formation of perceptions of cultural differences as a source of social progress and self-improvement; education of a 
respectable attitude of a pet to native culture; stimulation of cognitive interest in other cultures; development of knowledge, skills and skills of intercultural communication. In order to successfully implement the cross cultural education in the classroom, the teaching staff must be educated on these issues and their significance in the classroom. There are three aspects that focus on multicultural training: theory, society, and class. Learning about cross-cultural can be extremely diverse and implemented in a variety of forms, including seminars, conferences, information gathering and courses. However, future teachers should take part in several courses or seminars on cross-culturality, because studies show that one course does not have a lasting effect on teaching a student. The more information a teacher learns about multicultural education, and the more he develops his cultural competence, the better. Cross-cultural education is a complex subject, and one course can not fully teach future educators everything they need to know on this topic. There is a need for a combination of practical application with training, which will usually positively affect the cultural sensitivity of the future teacher. Classical cultural diversity is not a given formula for each environment, it is important for people to have experience in different settings to see how cross-culture is manifested there. Another factor that implements the implementation of cross cultural development is the support of the teachers they receive after studying. Cross culture in education should be a broad initiative of the university. Each member of the team should be involved in the implementation of cross-cultural in their practice to improve the participation of all participants. Cross cultural education should be carried out in a system involving future teachers, experienced teachers and administration at all levels. At present, the education system is not approaching the implementation of a cross-cultural education system approach. Turning to cross cultural issues or attempts to include multicultural elements in the classroom, teachers often apply the superficial approach considered earlier, since it is seen as a safe and positive way. A more in-depth analysis of cultures, including the consideration of historical and current relations between different cultures, is perceived negatively and is not realized as a strategy. This is probably due to the discomfort felt by teachers who consider themselves not ready for multicultural education. Traditional teacher training programs do not help prepare future teachers for work with a variety and risky issues/topics that may arise. Cross cultural training requires the formation of culturally competent teachers, preparing them for solving delicate issues. Often students are faced with inconvenient questions behind the doors of the classroom. Solving these issues openly in class can help students get accurate information and understand all aspects and points of view on the problem. Teachers and students can work towards preventing problems that may arise.

Types of multicultural training for teachers differ according to the stated goals, in particular: teaching culturally diverse students: developing the skills needed to assimilate into a dominant cultural background and help students withstand injustice and depression; knowledge of cultural pluralism in order to promote cross-cultural understanding and respect for cultural diversity; knowledge for cultural pluralism in order to preserve culture, enhance ethnic identity, encourage the social and political participation of minority groups, orientated to the general school experience on diversity; bilingual education, as a contribution to multicultural students in learning languages and skills, in-depth in dominant cultures, and in support of their own culture; multiculturalism is a normal human experience through which students learn how to live and work in a multicultural environment.

Professional value orientations have a decisive influence on both professional and personal self-determination of the future teacher, and all of their pedagogical activity is mediated. In relation to professional activity, researchers distinguish between values: the values of the profession associated with self-importance in professional activities; the values of professors arising from various types of remuneration of professional activities on the part of society; values that are formed on the basis of various features of one or another profession; higher quality values used in society for regulating the attitude of the profession. Thus, the analysis of scientific sources on the problem of the essence and role of values and value orientations allows us to conclude that, firstly, value orientations are a means of detecting a subject the attitude of the individual towards the environment, and, secondly, value orientations can be considered an integral mental tumor, which ensures the integrity of the consciousness, the emotional-sensory sphere and the behavior of the subject, and therefore their development is an effective mechanism of the solution formation of professionally significant personal qualities of the future teacher as subject of professional activity. It is necessary to overlook the fact that the process of forming valuable orientations of future educators is realized more to a higher education system. It is the pedagogy, giving students all the necessary knowledge, skills and abilities, instilling and forming the value orientations necessary for further professional development. Valuable orientations of teachers not only determine the motivation of their behavior, but also shape the outlook and future professional orientations. 
Conclusions. So, summing up, taking into account all the above, we can state that the activity of the teacher at the specialized department of teaching the future teacher of elementary school to form the moral and spiritual values of primary school age children is very important.

During the preparation of students the teacher should have theoretical knowledge in matters of moral and spiritual values, take into account the cross culture of the state, tolerance of the state policy in the field of multiculturalism. The university teacher must also possess a number of innovative technologies that will help him form in future became s real professional.

\section{REFERENCES}

1. Бех И. Д. Избранные научные труды. Воспитание личности // Избранные научные труды: в 2 тт. Черновцы: Букрек, 2015. 640 с.

2. Бех И. Д. Природа духовного у человека. Воспитание произвольного побуждения как средства овладения воспитанником духовной ценностью // Методист. 2015. № 11 (47). С. 18-26.

3. Молодиченко В. В. Реалізація гуманістичної особово-розвивальної парадигми в сучасній освіті [Електронний ресурс]. Режим доступу: http://virtkafedra.ucoz.ua/el_gurnal/pages/vyp9/molodychenko.pdf

4. Banks J. Multicultural education: issues and perspectives. Boston:Allyn\&Bacon,1997.-446p.

5. BennettC. Comprehensive multicultural education: theory and practice / ed. by ChristineBennett. MA:Allyn\&Bacon, 1999. 440p.

6. Berry J. W. Immigration, acculturation and adaptation. Appliedpsychology: Aninternationalreview. 1997.Vol . 46(1).5-68.

7. Cross-cultural psychology: research and applications / Berry J.W., Poortinga Y. H., Segall M. H., Dasen P. R.]. Cambridge: CambridgeUniversityPress, 1992. 208. 